\title{
Hâfız-ı Kütübden Kütüphaneciye: Osmanlıdan Günüimüze Bir Mesleğin Gelişimi
}

\section{From Hâfiz-ı Kütüb to Librarian: The Historical Development of Library Profession from Ottoman Empire to the Present}

\author{
Ekrem $\operatorname{Tak}^{1}$ (1)
}

${ }^{1}$ Sorumlu yazar/Corresponding author: Ekrem Tak (Dr. Öğr. Üyesi),

İstanbul Medeniyet Üniversitesi, Edebiyat Fakültesi, Bilgi ve Belge Yönetimi Bölümü, İstanbul, Türkiye E-posta: ekrem.tak@medeniyet.edu.tr ORCID: 0000-0003-1386-6519

Başvuru/Submitted: 13.04 .2020

Revizyon Talebi/Revision Requested: 04.05.2020 Son Revizyon/Last Revision Received: 20.05.2020 Kabul/Accepted: 24.05 .2020

Atıf/Citation: Tak, E. (2020). Hâfız-1 kütübten kütüphaneciye: Osmanlıdan günümüze bir mesleğin gelişimi. Bilgi ve Belge Araştırmalar Dergisi, 13, 81-102.

https://doi.org/10.26650/bba.2020.13.04
ÖZ

Kütüphanecilik, kütüphanelerin ortaya çıkışılla birlikte gelişen dünyanın eski mesleklerinden biridir. Buna bağlı olarak kütüphaneciler de antik çağlardan günümüze kadar bilgi hizmeti veren eski bir mesleğin mensuplarıdır. Bu çalışmada kütüphaneciliğin meslekî bir formasyon olarak gelişimi ve kütüphanecilerin (hâfız-1 kütüblerin) Osmanlıdan günümüze kadar değişen rolleri incelenecektir. Bu süreç hâfız-1 kütüblüğün ortaya çıkışından Tanzimat'ın ilanına kadar, Tanzimat'ın ilanından Cumhuriyet'in ilanına kadar ve Cumhuriyet'in ilanından günümüze kadar üç dönem halinde değerlendirilecektir. Bu üç döneme ait tespit edebildiğimiz belgeler ve kaynaklar ışığında hâfız-1 kütüblerin görevlendirilme şekilleri, sorumlu oldukları işler ve dönemler arasındaki farklar tespit edilecektir. Osmanlı dönemine ait birinci kısım kütüphane vakfiyeleri üzerinden incelenerek değerlendirmeler yapılacaktır. Hâfız-1 kütüb terimi geçen kütüphane vakfiyelerinde kütüphanecilik mesleğinin izleri aranacaktır. Yine Osmanlı dönemine ait ikinci kısım için bu dönemde kurulmuş modern okul kütüphanelerinin kuruluş nizamnameleri değerlendirilecektir. Modern okul kütüphanelerinde istihdam edilen hâfiz-1 kütübler ile vakfiyeler aracılığı ile atanan hâfız-1 kütübler arasında herhangi bir fark olup olmadığı araştırılacaktır. Üçüncü kısımda ise Cumhuriyet döneminde atanan kütüphaneciler incelenecektir. Bu dönemde kütüphanecilerin nasıl eğitim aldıkları ve nasıl uzmanlaştıkları incelenecektir. Son olarak Türkiye'de başlayan kütüphanecilik eğitimi faaliyetleri araştırılacaktır. Kütüphanecilik eğitimlerinin önce kurslar daha sonra üniversitelerde lisans seviyesinde eğitim almalarına kadar geçen serüven anlatılacaktır.

Anahtar kelimeler: Kütüphane, Kütüphaneci, Bilgi ve Belge Yönetimi

\section{ABSTRACT}

Librarianship is one of the oldest professions that has developed with the emergence of libraries. Accordingly, librarians are an old professional group that has provided information services from ancient times to the present. This article examines the process of the historical development of librarianship as a profession and the changing roles of librarians (hâfiz-1 kütüb) from the Ottoman Empire to the present. This historical process will be analyzed in three periods: the first period covers the time from the appearance of professional librarians to the declaration of Tanzimat, the second period is from the declaration of Tanzimat to the proclamation of the Turkish Republic and the third period is from the proclamation of the Turkish Republic to the present. It will be made evaluations about hafizı kütüp by examining the foundation deeds of the endowment libraries in the first period of Ottomans. The establishment regulations of the modern school libraries will be examined in the second period. It will be investigated whether there is any difference between the librarians employed in modern school libraries and those appointed through the foundation deeds. In the third period, the librarians appointed during the Republic era and the education of the librarianship will be examined.

Keywords: Library, Librarian, Information and Records Management 


\section{EXTENDED ABSTRACT}

Librarianship is one of the oldest profession in the World that has developed with the emergence of libraries. Accordingly, librarians are an old professional group that provides information service from ancient times to the present. This article attempts to examine the process of the historical development of the librarianship as a profession and the changing roles of the librarians (hâfiz-1 kütübs) from Ottoman Empire to the present. This historical process will be analyzed in three periods; the first period covers the time from the appearance of professional librarian to the declaration of Tanzimat, the second period is from the declaration of Tanzimat to the proclamation of Turkish Republic and the third period is from the proclamation of the Turkish Republic to the present. In the light of the documents and sources belong to these three periods, the system of selection and appointment of the librarians (hafızı kütüp), the duties and responsibilities which had to be met and the differences between the periods are determined.

The period from the appearance of librarianship (Hafiz-1 Kutubluk) to the declaration of Tanzimat is examined based on the deeds and the documents of the foundations established in the Ottoman Empire. A serach is made for traces of the profession of librarianship in the foundation deeds in which a mention of "hafiz kütüp" was made. It can be seen that there is no legal arrangement, regulation, or provision regarding the work to be done by librarians in the early period of the Ottomans. Librarianship as a profession started to develop in the 15th century, and the job descriptions of librarians were first discovered in the foundation deeds of the endowments established in the period of Fatih the Conqueror. However, the deeds of these endowments focused more on the duties to be performed by the librarians rather than the qualities sought in the candidates to be employed in the libraries. There is no provision made in the foundation deeds for the qualifications of candidates for the post of librarian until the period of Tanzimat Reforms. During this period, it was only stipulated that the candidates should be trustworthy, knowledgeable and religious.

The process from the declaration of Tanzimat to the proclamation of the Turkish Republic is examined looking through the regulations of the schools established in this period. There is an investigation into if there is a difference between the librarians (hafızı kütüb) employed in modern school libraries and those appointed through the foundations deeds. It can be observed that the process of change in the profession of librarian started through the new technical schools established outside the madrasa system. Even though we see the proliferation of the conditions required to be met by the librarians in the libraries established after the Tanzimat period, librarianship was neither defined as a professional field of study and practice, nor were candidates sought who possessed any educational and professional qualifications in order to be appointed to the librarian post. However, it is obvious that this situation started to change towards the end of the century. With the opening of various school libraries during the Tanzimat 
period, both the duties of librarians proliferated, and the qualities and conditions sought in them began to be specified, albeit partially.

The third period deals with those librarians appointed in the Republican era. The activities on the education of librarianship in the Republican era are examined through a literature review of the period. It can be observed that librarianship as a modern sense began in this period. An analysis is made of how librarians were trained and specialized in this period. Furthermore, an examination is made of the activities in the education of librarians which began in Turkey. The adventure of the education of the librarians from courses to undergraduate level at university is explained. In the Republican era, new professional qualifications started to be sought in librarians and the profession of librarianship could be described. The first step was to open librarianship courses, and existing librarians were obliged to attend these courses, and then those who wanted to become librarians were asked to obtain certificates from these courses. As of 1954, with the opening of the Department of Librarianship in Ankara University, those who want to become a librarian have to complete academic education at the university level. 


\section{GíRIŞ}

Tarihte kütüphanelerin ortaya çıkışıyla birlikte yeni bir meslekî formasyon alanı olarak gelişen kütüphanecilik, yüzlerce yıldır varlığını sürdüren bir meslektir. Kütüphaneciler antik çağlardan günümüze kadar bilgi hizmeti veren bir meslek olarak, bütün gelişmiş medeniyetlerin vazgeçilmez bir unsuru olmuştur (Bilgili, 2016, s. 3-4). Osmanlı döneminde başkent İstanbul' dan başlayarak Osmanlı coğrafyasının tamamında faaliyet gösteren büyük bir meslekî gurup olan kütüphaneciler incelemeye değer bir geçmişe sahiptir. Bu çalışmada kütüphanecilik mesleğinin Osmanlı özelindeki serüveni incelenecektir.

Osmanlıda kütüphanecilik mesleğinin tarihî gelişimi ve kütüphanecilerin formasyonları, Osmanlı kurumlarının yapısal özelliklerine göre farklılıklar veya benzerlikler gösterir. Bu farklılık, kütüphanenin içinde yer aldığı mekân ve işlevlerden kaynaklanır. Osmanlı kütüphaneleri tarihî süreçte öncelikle Osmanlı yönetim kurumlarının merkezi olan saraylarda padişahların hususî koleksiyonları olarak ortaya çıkmış ve zamanla kurumsal bir kimlik kazanmıştır. Saray kütüphanelerinden farklı bir tür olarak ortaya çıkan ve Osmanlı coğrafyasının tamamına yayılan medrese kütüphaneleri ise eğitim amaçlı kurulan kütüphaneler olarak gerek koleksiyonları gerekse kullanım amacı ve kullanıcıları bakımından diğerlerinden farklılıklar gösterir. Bunlar dışında camilerde kurulan kütüphaneler ise koleksiyon ve kuruluş amacı bakımından medrese kütüphanelerinden farklı olarak mahalle halkına da hizmet eder. Tekke kütüphaneleri koleksiyonları bakımından kısmî farklılıklar gösterse de amaç ve işleyişleri bakımından diğerleriyle benzer özelliktedir. Bütün bu kütüphane türlerinde ortak özellik ise hepsinin unvan olarak hâfız-1 kütüb adı verilen kütüphanecilerin sorumluluğunda bulunuyor olmasıdır. Hâfız-ı kütüb "kitapları ve kitapların bilgisini hıfzeden, koruyan" anlamında Osmanlı döneminde kütüphanelerde görevlendirilen meslek mensuplarının unvanı olarak 15. yüzyıldan itibaren kullanılmaya başlanmış ve Cumhuriyet dönemine kadar da bu kullanım aynıyla devam etmiştir. Bu meslek grubuna "emîn-i kütüb, hâzin, hâzin-i kütüb” denildiği de olmuştur (Erünsal, 1997, s. 94).

Osmanlının kuruluşundan bugüne kadar kütüphanecilik mesleğini üç dönemde incelemek mümkündür. Birinci dönemi ilk hâfız-ı kütüblerin ortaya çıkışından Tanzimat'ın ilanına kadar, ikinci dönemi Tanzimat'ın ilanından Cumhuriyet'in ilanına kadar, üçüncü dönemi ise Cumhuriyet'in ilanından günümüze kadar ele almak mümkündür.

\section{Osmanlı Vakıf Kütüphanelerinde Kütüphaneciler}

Osmanlı döneminde saray dışındaki kütüphaneler bir vakıf müessesi olarak kurulmuş ve her vakıfta olduğu gibi kütüphanelerle ilgili kuruluş ve işleyiş şartları vakıf kurucusu tarafindan vakfiyelerde belirlenmiştir. Bu sebeple hâfız-1 kütüblerin de tayin şekilleri, sorumluluk alanlarının neler olduğu, yapacakları işler ve alacakları ücretler vakıf kurucusu tarafından tespit edilmiştir. 
Her ne kadar Osmanlının erken dönemlerinde hâfız-1 kütüblerin yapacakları işlerle ilgili bir kânûnî düzenleme, nizamnâme veya talimatnâme mevcut olmasa da bunların İslam dünyasındaki kütüphanelerden çok farklı olmadığı söylenebilir. 16. yüzyılın büyük âlimlerinden Mısırlı Taceddin Es-Sübki'nin Mu'idü'n-Ni'am adlı eserinde kütüphanecinin görevleri tanımlanmıştır. Buna göre kütüphaneciler kitapları korumak, onarmak, ehli olmayanlara vermemek, diğer taraftan ihtiyacı olanlara ve fakirlere de mümkün olduğunca ödünç vermektir. Vakfiyede kitabın değerini karşılayacak kadar bir rehin bırakmadan dışarı, yani kütüphaneden çıkarılmasının yasaklandığı da bu metinde ifade edilmektedir.

Kütüphanecinin görevi kitapları korumak, bunlardan dağılmış ve yeniden tertibe ihtiyaç duyanları onarmak, onları ehil olmayanlara vermeyip aksine ihtiyacı olanlara vermeye çalışmak ve zenginlere göre kitap temin etmeleri zor olan fakirlere ödünç vermektir.

Vâkıfın, vakfiyede değerini karşılayacak kadar bir rehin bırakılmadan kitabın vakıf dışına çıkarılmasını yasaklayıcı bir şart koşması çokça karşılaşılan bir durumdur. Bu geçerli ve muteber bir şarttır. Dolayısıyla kütüphaneci bir rehin olmaksızın kitabı ödünç vermemelidir. (Taceddin Es-Sübki, 2019, s. 206)

16. yüzyıla ait mektup örneği bize hâfız-1 kütüblerin Mısır bölgesindeki görevlerini göstermesi bakımından ilginç detaylar barındırmaktadır. Mısır'ın Reşid şehrinde Mescid-i Mahallî’nin hâfız-1 kütübü olan İbrahim el-Menâdilî Câmiu'l-ezher şeyhlerinden İbrahim Demenhûrî’ye yazdığı bir mektupta kütüphaneyi nasıl idare etmesi gerektiğini sormuş. Demenhûrî verdiği cevapta hâfız-1 kütüblüğün bir ulema ve meşâyih (ilmiye) mesleği olduğunu ifade ederek bu mesleği ancak emanete riâyet eden, ilim sahibi, dindar kişilerin yapabileceğini söylemiştir. Hâfız-1 kütüblük yapacak kimsenin muhafazası altında olan kitapların ilim ehlinin yararlanması için vakfedildiğinin bilincinde olarak okuma, araştırma ya da kopya etmek için isteyenlere vermesi ve ayrıca ilim ehlinin kitaplardan daha iyi istifade edebilmesi için ilimlere göre tasnif edilmiş bir kataloğunu hazırlaması gerektiğini belirtmiştir (Erünsal, 2020, s. 157).

Osmanlının kuruluş döneminde hâfız-1 kütüblük hakkında bilgilerimiz çok sınırlıdır. Zira bu döneme ait kütüphane vakfiyelerinin çoğu günümüze ulaşmadığı gibi, vakfiyeleri bulunanlarda da bir hâfız-1 kütüb görevlendirilmesiyle ilgili herhangi bir bahis bulunmamaktadır. Hâfız-1 kütüblükle ilgili ilk şartlar ancak 15. yüzyılın ikinci yarısından sonra Fatih Sultan Mehmed'in (sal. 1444-1446, 1451-1481) hazırlattığı vakfiyesi ile karşımıza çıkmaktadır. Bu tarihten sonra kurulan kütüphane vakfiyelerinde de hâfız-1 kütüblere ve onlarda aranan niteliklere yer verilmeye başlanmıştır. Vakfiyelerde en çok üzerinde durulan kütüphane görevlisi hâfız-1 kütübdür. Diğer personel ancak bir iki satırla bazen de sadece ismen zikredildiği halde hâfız-1 kütüblerin vasıfları, tayin şekilleri ve yapmaları gereken işler vakfiyelerde ayrıntıları ile kaydedilmiştir (Erünsal, 2020, s. 335). 
Her ne kadar 15. yüzyıldan itibaren vakıf kurucuları tarafından vakfiyelerde hâfız-1 kütüblere yer verilmeye başlanmış ve kendilerinde aranan özellikler hemen hemen hepsinde belirtilmişse de, meslekî anlamda hâfız-1 kütüblerin eğitimi hakkında herhangi bir ipucuna rastlanılmamaktadır. Bu dönemde kurulan kütüphane vakfiyelerinin tamamı incelendiğinde hâfız-1 kütüblerde temel olarak aranan özellikler okuma-yazma bilmesi, kitabı koruması, kitaba zarar vermemesi, kitap ödünç verip-alması, güvenilir insan olmasından öteye geçmemektedir (Erünsal, 2017, s. 94). Mesela ilk defa hâfız-1 kütübten bahsedilen Fatih vakfiyesinde hâfız-1 kütübün kitap isimlerini bilmesinin yanı sıra, hoca ve talebelerin istedikleri kitaplar hakkında yeterli bilgiye sahip olması istenmiştir (Erünsal, 2020, s. 336). Daha sonraki tarihlerde tespit edilen kütüphane vakfiyelerinde de tayin olunacak hâfız-1 kütüblerde "mütedeyyin, mümin, emin”, "bir recül-i ârif ve sâlih-i zevi'l-ma‘ârif”, "emin, dindar, istikamet ve vakar sahibi”, "emin, salih ve eğitimli", "iyi huylu, istikamet sahibi, kitaplara vakıf, takva sahibi” olması gibi şartlar aranmıştır (Erünsal, 2020, s. 339). Görüldüğü üzere bu şartlar arasında hâfız-1 kütüblerden meslekî anlamda beklenen yegâne özellik kitap isimlerine vakıf olmasından öte geçmemektedir. İlerleyen tarihlerde elbette bunun istisnaî örnekleri ortaya çıkacaktır. Fakat 15. ve 16. yüzyıllarda kütüphanecilik mesleği açısından özel bir meslekî formasyonun olmadığı, iş tanımları yapılarak kütüphanecinin nelerle görevli olduğunun tanımlanmadığı kütüphaneciliğin bir meslek olarak henüz şekillenmediğini söylemek mümkündür.

Hâfız-1 kütüblüğün bu dönemde henüz müstakil bir meslek olarak kabul edilmediği bazı vakfiyelerde hâfız-ı kütüblerin kitapları muhafaza etme vazifesinin yanı sıra vakfın başka birimlerinde başka vazifeler yapmalarından veyahut vakfın başka işlerinde görevli olan kimselerin aynı zamanda hâfız-1 kütüb olarak da görevlendirilmiş olmalarından da anlaşılmaktadır. Mesela II. Selim'in Edirne'de yaptırdığı külliyenin 982 (1574-75) tarihli vakfiyesinde ikinci ve üçüncü hâfız-ı kütüblerden birinin yazı sanatında mâhir bir kâtip, öbürünün usta bir nakkaş olması şartı konmuştur (Erünsal, 2020, s. 338). Diğer bir örnekte Hacı Beşir Ağa 1148 (1735) tarihli vakfiyesinde, Eyüp’teki medrese kütüphanesinde görevlendirilecek üç hâfız-1 kütübden birinin medrese dışından diğerlerinin ise medrese öğrencileri arasından olmasını şart koşmuştur (Erünsal, 2020, s. 339). Şerif Halil Paşa ise Şumnu'da 1150 (1744) tarihinde yaptırdığı Camisi'nde kurduğu kütüphaneye hâfız-1 kütüb olacak kimseden kütüphanecilik vazifesinin yanı sıra, camide muvakkit olarak da görev yapmasını şart koştuğundan aranan hâfız-1 kütübün "fenn-i usturlabda mütefennin" olması istenmiştir (Erünsal, 2020, s. 340).

18. yüzyılda hâfız-1 kütüblük mesleğinin formasyon olarak müderris kökenli kimselere de açık hale geldiği ve bazı İstanbul kütüphanelerinde hâfız-ı kütüblerin kütüphanelerde ders vermeye başladığı vakfiyelerde bu yönde konulan şartlardan anlaşılmaktadır. Selim Ağa da 1197 (1782) tarihli vakfiyesinde Üsküdar'daki kütüphanesine tayin edilecek üç hâfız-1 kütübden ilk ikisinin bu vazifeleri ile birlikte kütüphanede ders vermelerini de şart koşmuştur 
ve bu sebeple buraya hâfız-1 kütüb olacak kişilerin Şeyhülislam tarafından imtihan edilmesini istemiştir (Erünsal, 2020, s. 340).

Hâfız-1 kütüblüğün bazı vakıf görevlerinin yanı sıra ikinci bir uğraş alanı olarak icra edildiği ve tekke şeyhi, türbedar, medrese müderrisi, şehir müftüsü, mahkeme kâtibi, mukayyid, hâne-i hassa sırkatibi, medrese öğrencilerinin en kabiliyetlisi, medrese softabaşısı, cami imamı, vaiz, müezzin, kayyum, mektep muallimi gibi farklı meslek ve formasyonlara sahip kimselerin hâfız-1 kütüb olarak tayin edilebildiği görülmektedir (Erünsal, 2020, s. 341).

Böyle bir durumda herhangi bir kütüphanecilik formasyonu olmayan hâfız-1 kütüblere kütüphanelerde bu meslekle ilgili ne tür sorumluluklar yüklenmekte idi? Vakfiyeler bu soru çerçevesinde incelendiğinde temel olarak hâfız-1 kütüblerden beklenen görevler kütüphanede bulunan kitapları korumak, istenen kitapları okuyucuya çıkarmak, vakfiye şartları müsait ise ödünç verip almaktı. Bununla birlikte kitap ve kütüphanenin güvenliği açısından kütüphaneye gelen okuyucuyu denetlemek, kitapları yırtılmaktan, kesilmekten, üzerine mürekkep dökülmesinden korumak da temel görevleri arasında idi (Erünsal, 2020, s. 345).

Bu anlamda Ragıp Paşa'nın 1762 tarihli kütüphane vakfiyesi önem taşımaktadır. Bu vakfiyede hâfız-1 kütüblükle ilgili o güne kadar diğer vakfiyelerde süregelen şartlar değiştirilmiştir. Ragıp Paşa vakıf şartları arasında hâfız-1 kütüblüğü babadan oğula geçen bir vazife olmaktan çıkarmış bunun yerine ulemadan müstehak olan ehil kimselerin hâfız-1 kütüb olması şartını getirmiştir (Cunbur, 1962, s. 11). Ancak ehil kimse şartı kütüphanecilik formasyonu açısından yeni bir durum olmakla birlikte, atanacak hâfız-1 kütübün nasıl ehil ve liyakat sahibi olacağı maalesef belirtilmemiştir. Hâfız-1 kütüblüğün babadan oğula geçmeyeceği şartı 1795 tarihli Konya'daki Yusuf Ağa Kütüphanesi vakfiyesinde de bulunmaktadır. Ne yazık ki bu vakfiyede de bir hâfız-1 kütübde aranan şartlar mesleki formasyon yerine bilgili, güvenilir, hoş yaradılışlı, ahlaklı kimse olarak tarif edilmiştir (Cunbur, 1962, s. 12).

15 Muharrem 1195 (11 Ocak 1781) tarihli I. Abdülhamid'in (sal. 1774-1789) vakfiyesinde Hamidiye Kütüphanesi için dört adet hâfız-1 kütüb tayin edilmiştir. Görevlendirilecek hâfız-1 kütüblerde aranan özellikler "iffet, sadakat ve salâh ve istikamet ile mevsuf olmaları" şeklinde ifade edilmiştir. Ayrıca bu dört hâfız-1 kütübün birincisine 120, ikincisine 100, üçüncüsüne 90, dördüncüsüne 80 akçe ücret ödeneceği şartı vardır. Her ne kadar aranan hâfız-1 kütüblerde kütüphanecilik mesleği adına bir özellik belirtilmemişse de ödenecek olan ücretler dönemin müderris ücretlerinden sonra diğer vakıf görevlileri arasında en yüksek ücretler olması dolayısıyla bu meslek grubuna verilen önemi göstermektedir (Cunbur, 1964/1, s. 27).

Osmanlı klasik dönemindeki hâfız-1 kütüblük mesleği de 19. yüzyıldan itibaren devlet ve toplum yapısının uğradığı büyük değişimle beraber bir farklılaşma göstermiştir. Bu dönemde kütüphaneler ve hâfız-1 kütüblük mesleği iki grup halinde incelenebilir. Bunlardan birincisi 19. 
yüzyıldan önce kurulmuş olan ve varlıklarını bu dönemde de devam ettiren vakıf kütüphaneleri ile Tanzimat'ın ilanından sonra yeni kurulan farklı türdeki kütüphanelerdir. ${ }^{1} 19$. yüzyılda vakıf usulüyle kurulan kütüphanelerin işleyiş ve atamaları yine vakfiye şartlarına göre yapılmaktaydı. Bu sebeple bu kütüphanelerde görev yapan bir grup hâfız-1 kütübün atama, tayin kriteri, maaş ve sorumlulukları eski klasik dönem vakıf şartlarına göre devam etmiştir.

\section{Okul Kütüphaneleri, Cemiyet Kütüphaneleri ve Umumî Kütüphaneler}

Osmanlı kütüphanecilik mesleğindeki değişim süreci medrese sisteminin dışında kurulan yeni teknik okullarla başlamıştır. Bu türden okul kütüphanelerinin ilk örneği 19. yüzyılın hemen öncesinde kurulmuş olan Mühendishâne kütüphanesiyle ortaya çıkmıştır. Okul kütüphanelerinin kurulmaya başlamasıyla önceleri görevleri vakfiyelerle tanımlanan kütüphanecilerin yerini daha kurumsal bir kimlik kazanmış ve görevleri nizamnâmelerle belirlenmiş kütüphaneciler almaya başlamıştır (Çavdar, 1995, s. 29).

Bunun örneklerinden biri olan ve 1775 'te eğitime başlayan Mühendishâne-i Bahr-i Hümayûn'da bir kütüphanenin varlığı hakkında bilgi yoktur ancak 1795'te açılan Mühendishâne-i Berrî-i Hümâyûn'un bir kütüphanesi mevcuttur. Bu kütüphanenin kurulma çalışmaları daha okul açılmadan önce 1794 senesinde başlamıştır. ${ }^{2}$ Mühendishâne kütüphanesi sadece klasik kitap muhafaza eden bir kütüphane değildir. Kütüphane aynı zamanda mühendislik alanında işe yarayacak alet ve edevatı da bünyesinde barındırmaktaydı. Bu alet ve edevat arasında çoğunlukla terekelerden satın alınarak ve ayrıca imal ettirilerek kütüphaneye kazandırılan haritalar, kale planları, marangozluk aletleri vard1 (Beydilli,1997, s. 288).

Mühendishâne kütüphanesinin kitapları ile alet ve edevatı ancak bir dolabı dolduracak kadar az sayıda olduğu için, 1796 senesine gelinceye kadar müstakil bir kütüphane yeri ve kitaplardan sorumlu bir kütüphanecisi yoktu. Öğrencilere kitapları ve alet-edevatı kullandırmak amacı ile 1797'de bir kütüphane nizamnâmesi çıkartılarak bir hâfız-1 kütüb tayin edilmiştir. Bu nizamnâmeye göre mevcut kitapların sağlam bir dolaba konularak anahtarının Mühendishâne hocasına verilmesine ve bu hocanın hâfız-ı kütüb unvanıyla atanmasına karar verilmiştir. Böylelikle Mühendishâne hocası Abdurrahman Efendi ilk hâfız-1 kütüb olarak tayin olunmuştur. Ancak kitapların kilitli dolap içinde olması nedeniyle Abdurrahman Efendi’nin olmadığı zamanlarda kitaplardan istifade etmek imkânı bulunmuyordu. Bu sebeple 1804 senesinde

1 Tuba Çavdar bu şekilde 70 kütüphane kurulduğunu tespit etmiştir (Çavdar, 1995, s. 5).

2 Mühendishâne kütüphanesinin kurulması, koleksiyonun geliştirilmesi ve bir kütüphane halini alması zaman içerisinde olmuştur. Kütüphane ilk olarak, III. Selim'in Enderûn-1 Hümâyûn'daki kitapları buraya naklettirmesiyle kurulmaya başlamıştır. Bu koleksiyon kütüphanenin uzun yıllar en önemli kısmını oluşturacaktır. Koleksiyonun gelişmesine ikinci büyük katkı ise 1801 yılında vefat eden Ebu Bekir Ratıp Efendi'nin terekesinde bulunan zengin kitapların ve mühendislik alet ve edevatının satın alınması ile sağlanmıştır. Daha sonraki yıllarda kütüphane mühendishanenin işine yarayacak kitap, alet ve edevatın devlet eliyle terekelerden satın alınarak ya da müsadere edilerek koleksiyona eklenerek geliştirilmiştir. Bunun yanı sıra kütüphanenin koleksiyonuna katmak amacı ile kitapçılardan da kitap satın alınmıştır (Beydilli, 1997, s. 277). 
Mühendishâne hocasının dışında müstakil bir hâfız-ı kütüb tayin edilmiştir. Mühendishâne kütüphanesinin ilk hâfız-1 kütübü Mühendishânenin beşinci mülazımlarından Hasköylü Ali veled-i Abdullah olmuştur (Beydilli,1997, s. 293).

1796 tarihli Nizamnâmeye göre hâfız-1 kütübün görevi kitaplara sahip çıkmak, korumak, dışarıya ödünç kitap ve alet edevat vermemek, görev değişikliği halinde yerine gelecek hâfız-1 kütübe bunları eksiksiz teslim etmek ve eğer eksik çıkarsa bunu tazmin etmek idi. Buradan Mühendishâne hâfız-1 kütüblerinin sadece kitaplardan sorumlu olmadıklarını, bunun haricinde kütüphanede bulunan alet ve edavatdan da sorumlu olduklarını görüyoruz ki bu da 19. yüzyılda hâfız-1 kütüblerin sorumluk alanlarının genişlediğini gösteriyor. Mühendishâne kütüphanesinde görev yapan hâfız-ı kütüblerin sorumluluk ve yetki alanlarına baktığımızda kütüphanecilik alanında yeni bir uygulama ile daha karşılaşıyoruz. Hâfız-1 kütüblerin nizamnâme kuralı gereğince dışarıya kitap, alet ve edevat ödünç vermesi yasaklanmıştı. Hâfız-ı kütübler ancak Mühendishâne nâzırının padişaha arzı ve bu arz üzerine yazılan fermân-ı âli yani padişahın izni ile kütüphane dışına ödünç kitap, alet ve edevat verebiliyorlardı. 822 yılında yeni çıkarılan bir nizamnâme ile de -ödünç verme hâfız-1 kütübün yetkisi dâhilinde olmadığı için- eksik çıkan kitap ve alet-edevatın hâfız-ı kütüb tarafından tazmin edilmesi kuralı tashih edilmiştir (Beydilli, 1997, s. 296).

19. yüzyılda batılılaşma ve modernleşme gayreti içinde açılan okullardan bir diğeri de Mekteb-i Cedîd-i Harbiyye-i Şâhâne'dir. 1834'te kurulan mektebin Mekteb-i Cedîd-i Harbiyye-i Şâhâne'nin İdâre-i Dâhiliyesine Dâir Kânânnâme adıyla 1253/1837 ve 1263/1847 tarihli iki yönetmeliği vardır. 1253/1837 tarihli kânûnnâmeye göre Mekteb-i Harbiye'nin personel kadrosu içinde hâfız-1 kütüb de gösterilmektedir. Kânûnnâmeye göre kütüphanede bir mütâlaa salonu, iki kitap deposu, bir numunehâne, bir laboratuvar bulunmakta olup, bunlar hâfiz-1 kütübün kontrolü altında idi (Gök, 2005, s. 80).

1263/1847 tarihli kânûnnâmede ise "Memurların adedi ve unvanı” başlığı altında mektebin iki adet "muhâfız-1 kütüb ve âlât”ının olduğu kaydedilmiştir. Kânûnnâmenin ilerleyen bölümlerinde "Hâfız-1 Kütüb, Muhâfız-1 âlâtın Me'mûriyeti” başlığı altında kütüphanedeki kitaplardan ve aletlerden bu memurların sorumlu olduğu ve görevlerinin neler olduğu belirtilmiştir (Mekteb-i cedîd-i..., 1263 [1847], s. 6).

Hâfız-1 Kütüb, Muhâfız-1 âlâtın Me'mûriyeti

Hâfız-1 kütüb ve muhâfız-1 âlât bulunan kimesneler ile hikmet-i tabi'iyye âlâtının muhâfazasına me'mûr olduklarından kütüb ve âlâtdan bir şey zâyi‘ yâhud harâb ve berbâd olur ise kendülerinden mes'ûl ola ve muhâfız-1 âlâtın âlât-1 mezkûreyi söküp temizlemek ve yerlerine takabilmek üzere ma'lûmât-1 kâfiyesi ola ve Hikmet-i tabî'iyye hocasın nezâretiyle tecârib-i hikemiyeye lâzım gelen âlâtı tehiyye ve ihzâr ede ve hasbe'l-icâb bir mahalle kitab ve âlât i'tâsı lâzım geldiği takdirde matlûb 
eden zâtdan Liva Paşa tarafından musahhah bir kıt'a makbûz senedi ahz etmedikce hiçbir kitâb ve hiçbir âlet vermeğe salâhiyetleri olmaya ve ondan sonra şey'-i mezkûr ol kimesneden su'âl oluna ve kütübhânede mevcûd olan cemî' kütüb ve âlâtı sebt-i defter edip defter-i mezkûrun bir aynı dahi Bâb-1 Seraskerî' de Ruznamçeye kaydettirilerek yeniden bir kitab veyâ bir âlet tedârik olundukca onu dahi deftere kayd ve ilâve edeler ve merkûmân Hikmet-i tabi'iyye hocasının ma'iyetine me'mûr olalar ve mekteb-i mezbûre lüzûmu takdîrinde bi'l-istid'â alınıp hâfız-1 kütübe teslîm olunarak icâbına göre şâkirdân vesâireye taksîm olunan kağıd ve kalem ve kurşun kalem ve boya vesâir buna mümâsil kâffe-i eşya bâlâda muharrer usûle tatbîken sened ahzıyla bi'l-i'tâ senedât-1 merkûme mûcibince beher-mâh hesâbı rü’yet kılına (Mekteb-i cedîd-i..., 1263 [1847], s. 18-19).

Metne göre bu memurların başlıca görevi kitap ve aletleri korumak, "Liva Paşa" tarafından tasdikli bir belge getirdikleri takdirde talep edenlere ödünç vermekti. Hâfız-1 kütübler ayrıca okul tarafından satın alınarak kendilerine teslim edilen kağıt, kalem, boya gibi sarf malzemelerini makbuz karşılığı hoca ve talebelere dağıtmaktan da sorumlu idiler. Kânûnnâmeye göre "hâfız-1 kütüb ve âlât” bu görevlerini Mekteb-i Harbiye'nin Hikmet-i Tabi ‘iyye hocasının kontrolü altında ifa etmekteydiler.

Mekteb-i Harbiyye'deki hâfız-1 kütüblerin diğer bir önemli görevi ise kütüphanede bulunan ve yeni gelen kitapları Bâb-ı Seraskerî'deki Ruznamçe defterine kaydettirmekti. Hâfız-1 kütüblerin görevleri arasında zikredilen bu gelen kitapların kaydedilmesi hususu, kütüphanecilik tarihimizde koleksiyona dahil edilen kitapların deftere kayıt usulünün en erken örneklerinden birini oluşturmaktadır. Daha önce vakıf kütüphanelerinde bu türden bir uygulama mevcut olmayıp, kütüphaneye vakfedilen kitaplar vakfiyede kaydedilmekte veya müstakil bir listesi hazırlanmakta idi. Hâfız-1 kütüblerin bu yeni görevi, kütüphanelerde koleksiyon geliştirme politikalarının uygulanmasına bağlı olarak ortaya çıkmış bulunmaktadır (Mekteb-i cedîd-i..., 1263 [1847], s. 18).

1827'de kurulan ve bir kütüphaneye sahip olan Mekteb-i T1bbiye'nin 1857 tarihinde kabul edilen nizamnâmesinde, hâfız-1 kütüblerin görev ve sorumlulukları açıkça belirtilmiştir. Ancak bu nizamnâmedeki hâfız-1 kütübler ile ilgili maddeler ile yukarıda bahsi geçen 1847 tarihli Mekteb-i Cedîd-i Harbiyye-i Şâhâne kânûnnâmesindeki maddeler birebir benzerlikler taşımaktadır. Zira "Hâfız-1 Kütüb, Muhâfız-1 âlât ve yardımcısının görevleri” başlığı altında kütüphanedeki kitaplardan ve aletlerden hâfız-1 kütüblerin sorumlu olduğu, başlıca görevlerinin kitap ve aletleri korumak, nazır muavininden tasdikli bir belge getirdikleri takdirde ödünç vermek, okul tarafından satın alınarak kendilerine teslim edilen kâğıt, kalem, boya gibi sarf malzemelerini makbuz karşılığı hoca ve talebelere dağıtmak olduğu aynı şekilde yazmaktadır. Harbiye-i Şâhâne'de Tabi'iyye hocasının sorumluluğu altında olan hâfız-1 kütübler burada Fizik hocasına bağlı olarak görev yapmaktadırlar. Ayrıca hâfız-1 kütüblerin kütüphaneye gelen 
kitapları Bâb-ı Seraskerî’deki Ruznamçe defterine kaydetme görevleri de bu nizamnâmeye aynen kaydedilmiştir ${ }^{3}$ (Günergun ve Yıldırım, 2001, s. 53).

1859 y1lında eğitime başlayan Mekteb-i Mülkiye’nin bir kütüphanesi mevcut olmakla beraber kütüphanecileri ve görevleri hakkında tespit edilebilmiş bir bilgi mevcut değildir. 1880 yılında okulun yatılı hale getirilmesi için hazırlanan raporda geçen "kütüphane memuru" ifadesi bir hâfız-1 kütübün görevli olduğunu göstermektedir (Çavdar, 1995, s. 35).

Kuruluş çalışmaları 1863 'te başlayan Darülfünun'un da bir kütüphanesi vardır. Darülfünun kütüphanesinin kurulmasıyla ilgili hükümler 1869 yılında yayınlanan Ma‘ârif-i Umûmiye Nizamnâmesi'nde yer almış ve kitapları korumak üzere bir kütüphane memuru tayin edilmiştir.

Ma'ârif-i Umûmiye Nizamnâmesi kütüphaneler ve kütüphaneciler açısından önemli bir nizamnâmedir. Çünkü Tanzimat’tan sonra batılı anlamda kurulan okul kütüphanelerinden resmî olarak ilk defa bu nizamnâmede bahsedilmiş ve bu okullar bu nizamnâmeye göre kurularak işletilmeye başlanmıştır. Nizamnâmenin kütüphaneciler açısından diğer bir önemi de daha önce "Evkâf-1 Hümâyûn Nezâreti"nin uhdesinde bulunan kütüphanelerin yönetim ve teftişi bu nizamnâme ile "Ma'ârif-i Umûmiye Nezâreti"ne geçmiştir (Türkmen, 2001, s. 646). Böylelikle kütüphaneler eğitimin bir parçası olarak addedilerek vakıf kütüphaneleri ile okul kütüphaneleri ayrımı belirlenmiş oldu (Candemir, 2004, s. 375). Nizamnâmenin 67 ., 119.-123., 138. ve 146.-148. maddeleri kütüphanelerle ilgilidir. Okul kütüphanelerinin resmi olarak zikredilmeye başlanmış olmasına rağmen Tanzimat'tan sonra kurulan her okulda bir kütüphanenin varlığından kesin olarak da bahsetmek mümkün değildir (Çavdar, 1995, s. 645).

Bu dönemde kurulan ve varlığını halen devam ettiren okullardan biri de Darüşşafaka'dır. Darüşşafaka 1864 senesinde kurulan Cemiyet-i Tedrisiye-i İslamiye tarafindan 1873 senesinde açılmıştır. Cemiyetin 1280/1864 ve 1289/1872 tarihli iki nizamnâmesi mevcuttur. Her iki nizamnâmede de hâfız-1 kütüblükle ilgili bir bilgi yoksa da, Cemiyet-i Tedrisiye-i İslamiye heyet-i umûmiyesinin 1910 tarihinde yaptığı bir toplantıda hâfız-1 kütüblükle ilgili şu kararı aldığı kaydedilmiştir: "Hâfız-ı kütüblük ile âlât muhâfızlığını mükeffil bir memurun tayinine ve kimya muallimi Cemiyet a'zasından ve mezunînden Cemal Efendi'nin fahriyen âlât-1 fenniyenin muhafazasına nezaret etmesine.” (Kılıç, 2016, s. 94).

19. yüzyılın sonlarına gelindiğinde okuma yazma oranının artması ile toplumun kütüphaneye olan ihtiyacı da artmış ve umûmî kütüphaneler kurulması fikri ortaya çıkmıştır. Bu anlamda ilk kurulan kütüphanelerden biri 1298/1881 tarihinde açılan Şam Kütübhâne-i Umûmîsi’dir. Kuruluş talimatnâmesine göre Şam umûmî kütüphanesine iki hâfız-1 kütüb tayin edilerek aylık 200'er kuruş maaş tahsis edilmiştir (Çavdar, 1995, s. 56). Talimatnâmenin 8. maddesinde hâfız-1 kütübün görev ve sorumlulukları şu şekilde belirlenmiştir:

3 Nizamnâme metni sadeleştirilmiş olarak (Günergun ve Yıldırım, 2001) tarafından yayınlanmıştır. 
Hâfız-1 kütüblerin vezâif-i mahsûsası her gün vakt-i mu'ayyende kütübhâneyi açıp bir mâni'-i zarûrî ve şer'î vukû'uyla heyet-i cem'iyetden istizân etmedikce işleri başından akşama kadar ayrılmamak ve orada mevcûd olan kitapları dâima hüsn-i tertîb ve intizâm ve nezâfet üzere tutmak ve ashâb-1 mürâca'âta hürmet ve ri'âyetle mütâla'asını arzu eyledikleri kitabı derhal bulup kendilerine vermek ve kütüb ü resâil-i mevcûdenin te'lîf ve tertibince noksanları bulunduğu halde onları nüsâh-1 kâmileden bi'l-istinsâh ikmâl eylemek gibi hizmetlerden ibâret olarak... (Erünsal, 1990/2, s. 394).

Buna göre hâfız-1 kütübler noksan olan kitapları istinsah ederek tamamlamakla sorumludurlar. Ayrıca kütüphaneden kaybolan kitaplardan da hâfız-1 kütübler sorumludur. Üç ayda bir yapılan kontrollerde ikinci defa kitap kaybettiği anlaşılan hâfız-1 kütüb işten çıkarılacaktır (Çavdar, 1995, s. 56).

Tanzimat'ın ilanından sonra modern okulların açılması ve birçoğunda kütüphaneler kurulmasına paralel olarak resmi dairelerde, cemiyet ve derneklerde de kütüphane açma faaliyetleri gerçekleşmiştir. Bu türden kütüphanelere ilk örnek 1861'de kurulan Cemiyet-i İlmiye-i Osmâniye Kütüphanesidir. Cemiyet-i İlmiye-i Osmaniye Osmanlılar zamanında kurulmuş batılı anlamda ilk dernek ve dernek içindeki kütüphane de batılı esaslara göre kurulacak modern bir kütüphanenin ilk adımı olarak kabul edilmiştir (Cunbur, 1967, s. 692). 1862 yılında cemiyet için Nizâmât-1 Cemiyet-i İlmiye-i Osmâniye başlı̆̆g altında bir nizamnâme yayınlanmıştır. Nizamnâme, kitap kayıtlarını bir ileri aşamaya taşıması bakımından önemlidir. Artık araştırmacılar kitapları defterler üzerinden kitap veya yazar adına göre alfabetik olarak arayabileceklerdir. Bu nizamnâmenin üçüncü maddesine göre hâfız-1 kütübler üç defter tutacaklardır. Bu defterlerden birincisi, sağlama sırasına göre düzenlenecek; kitapların sağlandığı tarih, kitap isimleri ve bedelleri yazılacaktır. Kitabın hediye olması durumunda ise hediye eden kişinin adı kaydedilecektir. İkinci defterin, kitap veya yazar adına göre alfabetik düzende tutulacağı bildirilmiştir. Üçüncü defterde ise kitapların konusal sınıflandırılarak listelenmesi istenmektedir. Ancak, hafız-1 kütüblerin uyması ve uygulaması gereken sınıflama sistemine veya uyulması gereken bir kurala işaret edilmemiştir. Dördüncü maddeye göre ise cemiyet üyelerinden biri kitap ödünç almak isterse, hâfız-1 kütüb kitabı teslim edecek ve teslim edildiğine dair tarihli, imzalı bir senet düzenleyerek kitap iade edildiğinde bu senedi okuyucuya iade edecekti. Ayrıca hâfız-ı kütüb ödünç verdiği bu kitaplarla ilgili ayrı bir defter tutacaktır (Erünsal, 1990/1, s. 317-318).

Üçüncü madde- Hâfız-ı kütüb üç defter tutacak olup bunların birisine kitabların târih-i tedârikleri tertibiyle isim ve bahâları veyâhud ihdâ eden zevâtın isimleri ve ikincisine hurûf-1 hecâ tertibi üzere kütüb-i mezkûre veyâ müe’elliflerinin esâmîsi yazılacak ve üçüncüsünde her fenne müte'allik kütüb başkaca bir cedvel-i mahsusa kaydolunacaktır. 
Nizamnâmeye göre hâfız-1 kütübler cemiyet üyeleri arasından seçilecek ve ücretsiz hizmet edeceklerdir. Hâfız-1 kütübün görevleri nizamnâmenin 15. ve 25. maddelerinde ifade edilmiştir. Bu maddelere göre hâfız-1 kütüblerin vazifelerini nizamnâmeye göre ifa edecekleri ve cemiyete hediye edilecek eski eserlerin hâfız-1 kütübün sorumluluğu altında olacağı ifade edilmiştir (Cunbur, 1964/2, s. 693).

Hâfız-1 kütüblere idare heyeti içinde yer veren ve bu bakımdan da bir ilki teşkil eden Cemiyet-i Tıbbiye-i Osmaniye, resmî olarak 1865 yılında kurulmuştur. Cemiyetin kuruluş nizamnâmesine göre idare heyeti üyelerinden biri de hâfız-1 kütübtür. Nizamnâmeye göre hâfız-1 kütüb kitaplara nezaret edecek, kütüphanede mevcut kitaplar ile bir sene içinde basılacak kitapları listeleyerek ayrı birer defter tutacaktır (Çavdar, 1995, s. 53).

1297/1881 senesinde "Kütüphanelerin sûret-i idaresi hakkındaki talimatnâme” adıyla İstanbul'da bulunan kütüphanelerin ne durumda olduklarını gösteren bir talimatnâme yayınlanmıştır. Maarif Nazırı Münif Paşa ve Erzurumlu Ethem Pertev Paşa tarafından hazırlanan ve dönemin Sadrazamı Ali Paşa'ya sunulan talimatnâme kütüphanecilik tarihinde kütüphanelerle ilgili ilk resmi talimatnâme olarak kabul edilmiştir. 19 maddeden oluşan talimatnâmenin 13.-16. maddeleri hâfız-ı kütübler ile alakalıdır. Ancak burada da bir meslek olarak hâfız-1 kütüblerde aranan özelliklerden ziyade onların kütüphanelerde ne tür işlerden sorumlu oldukları vurgulanmıştır. Buna göre hâfız-1 kütübler hiç kimseye ödünç kitap veremeyecekler, kitapların kaybolması halinde zararı yine hâfız-1 kütübler tazmin edeceklerdir. Talimatnâmede ayrıca hâfız-1 kütüblerin görevlerinin başından ayrılmamaları, ayrılmaları halinde yerine vekil bırakmaları tembih olunmuş ve vefatları halinde yeni atanacak kişinin nasıl tayin olunacağına dair bilgiler verilmiştir (Cunbur, 1964/3, s. 33-34; Cunbur, 1964/2, s. 697; Çavdar, 1995, s. 78-79).

Bundan bir yıl sonra İstanbul'daki kütüphanelerin de yetersiz ve birbirinden uzak olduğu tespit edilerek Bayezid külliyesi içerisinde bir Kütüphâne-i Umûmî-i Osmânî açılmasına karar verilmiştir. 1884 yılında açılan kütüphaneye 3 hâfız-1 kütüb tayin edilmiş ve bunlardan birinin Fransızca bilmesi şart koşulmuştur. Fransızca şartını sağlayan hâfız-1 kütübe 600 kuruş maaş tahsis edilirken diğer hâfız-1 kütüblere aylık 200'er kuruş maaş tahsis edilmiştir (Çavdar, 1995, s. 60). Başka bir dil bilme şartı, hem değişen kütüphane koleksiyonlarının gerektirdiği bir şart olarak düşünülmüş olsa da kütüphanecilerde olması beklenen; ölçülebilir ve değerlendirilebilir vasıfların da yavaş yavaş seçim şartlarının arasına girmeye başladığını göstermektedir.

1883 yılında Şurâ-yı Devlet Tanzimat Dairesi tarafından Osmanlı vakıflarında ve kurumlarında çalışan tüm personelin tayin ve görevlendirilmeleri ile alakalı 15 maddelik bir lâyiha yayınlanmıştır. Lâyihanın 2. maddesi hâfız-1 kütüblerin tayin ve atamaları ile ilgilidir. Bu maddeye göre hâfız-1 kütüblüğe yeni atanacak kimselerin ilim ve fen kitaplarını üç dilde tasnif edecek kadar Arapça ve Farsça bilmeleri ve yapılacak bir imtihan ile bunu göstermeleri şartı getirilmiştir. Lâyihanın 6. maddesinde ise hâlihazırda hâfız-1 kütüb olarak çalışanların 
da aynı şartları yerine getirmeleri istenmiştir. Hâfız-ı kütüb olarak çalışanlar eğer bu şartları haiz değiller ise işten geçici olarak el çektirilerek 6 ay süreyle eksikliklerini tamamlamaları ve yapılacak imtihanda başarılı olmaları şartı getirilmiştir. 6 ay sonunda imtihanda başarılı olamayanlar işten tamamen el çektirilecektir (Çavdar, 1995, s. 84-85).

II. Abdülhamid döneminde (sal. 1876-1909) kütüphanecilik alanında birçok çalışmalar yapılmıştır. Bu çalışmalardan birisi de Maarif Nezareti tarafından hâfız-1 kütüblüğe tayin işlerini kontrol altına almaktır. Maarif Nezareti'nden Sadaret'e yazılan 1884 tarihli bir yazıda atanacak olan hâfız-1 kütüblerin ehliyetlerini tespit için ne yapmak gerektiği ve mevcut hâfız-1 kütüblerin nasıl ıslah edileceği hakkında görüşler bildirilmiştir. Buna göre hâfız-1 kütüblerin bir kitabın hangi ilim dalı ile alakalı olduğunu ve hangi dilde yazıldığını anlayacak kadar okuma yazma bilmeleri ve bunun yanında Arapça ve Farsçaya da vâkıf olmaları gerektiği belirtilmiştir (Erünsal, 2010, s. 370). Yapılan sınavlarda ise hâfız-1 kütüb adaylarına Arapça ve Farsça beyitler verilerek bunları okumaları ve tercümelerini yapmaları istenmiştir. Bazı sınavlarda ise hâfız-1 kütüb olmak isteyenlere basit toplama-çıkarma işlemleri sorulmuştur (Erünsal, 2012, s. 168).

Fetva Emini Nuri Efendi'nin 27 Receb 1318/20 Kasım 1900 tarihinde kütüphaneler hakkında hazırlamış olduğu önemli bir rapor vardır. Rapora göre mevcut kütüphanelerin durumu çok kötü bir vaziyette olup birçoğunun kapıları mühürlü, açık olanlarında bulunan kitaplar dağılmış ve toz içinde olduğu ifade edilmiştir. O günkü şartlarda zayi olduğu takdirde yerine yenisini konamayacağı kadar kıymetli kitapların korunması için görevli kütüphanecilerin ise maaşlarının padişahın bu konudaki isteklerinin aksine çok düşük miktardadır. Mesela Şehid Ali Paşa Kütüphanesinde görevli kütüphaneci maaşı yüz para, Köprülü Kütüphanesi kütüphanecilerinin maaşları otuz kuruştur. Bu durum kıymetli kitapların muhafazası için önemli bir sorundur. Nuri Efendi'nin raporunun konumuz açısından diğer bir önemli yanı ise kütüphanelerde görevli kimseler için hâfız-1 kütüb ifadesi yerine -günümüz kütüphanecilik meslek mensubunu ifade etmek için kullanmakta olduğumuz- kütüphaneci kavramının kullanılmış olmasıdır (Erünsal, 1990, s. 369).

Kütüphaneci olarak istihdam edilen personelin formasyonu bakımından belli nitelikler arayan İstanbul Arkeoloji Müzesinin ayrı bir önemi vardır. 1903 yılında faaliyete geçmiş olan bu kütüphane müzecilik, arkeoloji, sanat tarihi gibi konularda bir koleksiyon oluşturmaya çalışmış ve bu açıdan bir ihtisas kütüphanesi olarak tanımlanabilecek ilk kütüphanelerdendir. Bu kütüphanenin araştırma kütüphanesi olması hasebiyle personelinin de özel uzmanlık alanlarına sahip kimselerden seçildiği görülmektedir. Bu personel konu sınıflandırması yapabilen, tarih, arkeoloji ve müzecilik konularında uzman ve o devrin kütüphanecilik tekniklerine vâkıf kimselerdir. ${ }^{4}$

4 İstanbul Arkeoloji Müzesi Kütüphanesine Maarif Nezareti tarafından ilk atanan kişi "muhafız" unvanı ile Baltacızade Todoraki Bey'dir. Todoraki’nin ölümü üzerine yerine atanan kişi ise Almanya Darülfünun'unda tarih ve eski eserler eğitimi almış ve eserler yayınlamış olan Selanik Rum Ortodoks Mektebi Müdürü Mistakidis Efendi'dir (Koç, 2015, s. 155). 
Ahmed Zeki Bey’in İstanbul kütüphanelerinin durumu ve görülen aksaklıkların düzeltilmesi hakkında Sadrazam Hüseyin Hilmi Paşa’ya (1855-1923) 1909 tarihinde verdiği bir takrirde, dönemin hâfız-1 kütüblerinin durumu açıkça ortaya konmuştur. Ahmed Zeki Bey’e göre hâfız-1 kütübler öncelikle kendilerine emanet edilen hazine değerindeki kitapların önemini anlamak ve kendilerine müracaat eden ilim ehline yardımcı olmak zorundadırlar. Ancak İstanbul kütüphanelerinde bulunan hâfız-1 kütüblerin durumları bunun tam tersidir. Durum her ne kadar böyle ise de Ahmed Zeki Bey bunun mazur görülmesi gerektiğini ifade etmiştir. Çünkü o dönemde bir hâfız-1 kütübün maaşı 25 ile 120 akçe arasında olup bu para kıymetli bir hazinen koruyucusunun değil, bir hizmetçinin bile zaruri ihtiyaçlarına yetmeyecek derecededir. $\mathrm{Bu}$ sebeple raporda açılması teklif olunan Kütübhâne-i Osmânîde çalışacak bir hâfız-ı kütübün maaşının 10-15 liradan aşağı olmaması gerektiği belirtilmiştir (Erünsal, 1990, s. 330-332). Hal böyle bile olsa hâfız-1 kütüblerin kütüphanelerin açılış ve kapanış saatlerine dikkat etmeleri gerekmektedir. O dönemde İstanbul'da hâfız-1 kütübler kütüphaneleri her gün açmadıkları gibi, açtıkları gün de öğleden sonra açıp, ikindiden evvel kapatmaktadırlar. Kütüphanelerin hâfız-1 kütüblerin keyfine göre açılıp kapanması buralara müracaat edecek ilim ehlinin istifadesi açısından son derece mahzurludur (Erünsal, 1990, s. 335). Ahmed Zeki Bey, kütüphanecilerin yerine getirdikleri görevleri bir iş değil bir meslek olarak görmeleri gerektiğini farklı ifadelerle dile getirirken, aynı zamanda onların ekonomik durumlarının iyileştirilmesinin, meslekî aidiyeti güçlendireceğini de öne sürmektedir.

Tanzimat'ın ilanından sonra okul kütüphanelerinin açılmaya başlanmasından sonra, kütüphanecilik alanındaki gelişmelerin eğitim alanındaki gelişmelere bağlı olarak şekillendiği ve eğitim alanında yeni hükümler çıkarılmasıyla kütüphanecilik mesleğinin de değişime başladığı görülmektedir (Soysal, 1976, s. 251). Zira Ma‘ârif-i Umûmiyye Nizamnâmesi’nin yayınlanması bu döneme denk gelir. Böylelikle o zamana kadar vakıflar aracılığı ile işletilen kütüphaneler bu dönemden sonra devlet tarafından açılmaya başlamıştır (Soysal, 1976, s. 255).

\section{Türkiye Cumhuriyeti’nin İlk Yıllarında Küiüphaneci Atamaları}

1 Haziran 1924 tarihli Mihrab Dergisi’nde “Kütüphanelerde Islahat Münasebetiyle” başlığı altında kütüphanelerle birlikte hâfız-1 kütüblerin de 1slah edilmesi gerektiğine dair bir yazı yayınlanmıştır. Yazıda daha önce Evkaf ve Şer'iyye Vekâletine bağlı olup daha sonra Maarif Vekâletine devredilen vakıf kütüphanelerinde hâlihazırda görev yapan hâfız-1 kütübler içerisinde ismini dahi yazamayacak kimselerin bulunduğu ifade edilmiş ve kütüphanelerde birçok kıymetli eserin bakımsızlık sebebi ile mahvolduğu kaydedilmiştir. Bu sebeple birçok hâfız-ı kütübün tasfiye edilerek yerlerine ilim ve fazilet sahibi kimselerin atanması gerektiği ifade edilmiştir. Bundan sonra hâfız-1 kütüb olacakların da Darülfünun mezunu ya da en azından öğrencisi olması şartı aranması teklif olunmuştur (A. Fuad, 1340 [1914], s. 451). 
1924 yılında hazırlanan ancak hayata geçirilmeyen "İstanbul Darülfünun Kütüphanesi Dâhili Nizamnâmesi" Cumhuriyet döneminin kütüphanecilik alanındaki ilk lâyiha olması dolayısıyla kütüphaneler ve kütüphaneciler açısından önemlidir. Hukuk Fakültesi Kütüphanesinde çalışan bir memur tarafından hazırlanan lâyihanın kütüphaneciler açısından önemi, kütüphaneciyi klasik dönem vakıf kütüphanelerinde sadece kitapları korumakla görevli bir memur yerine yükseköğretim okulu kütüphanesinde bir yönetici olarak göstermektedir. Zira lâyihanın 4. maddesine göre kütüphane yönetimi her fakültede bulunan müderrisler meclisi tarafindan atanan bir müderris, Darülfünun Emaneti tarafından atanan bir kişi ve kütüphane memurundan oluşturulacaktır. Lâyihanın kütüphanecilik mesleği açısından diğer bir önemi ise lâyihada bir kütüphane müdürünün adının geçmemesi bunun yerine sadece kütüphane memuru ifadesinin geçmesidir. Ayrıca lâyihada hâfız-ı kütüb ibaresinin yerine "kütüphane memuru" ifadesi kullanılmıştır (Candemir, 2004, s. 376).

Darülfünun emini tarafından atanan kütüphane memuru görevleri lâyihanın 12.-17. maddelerinde belirtilmiştir. Buna göre kütüphane memuru 1- İdare meclisinin kararlarını uygular, 2- Diğer personelin çalışmalarını düzenler, 3-Bütçeyi kullanır, 4-Müfredat Defterindeki (Envanter) kayıtları Tertîb-i Deftere (kataloğa) kaydeder, 5- Sene sonu kütüphanenin son durumunu içeren mesai ve ücret raporu düzenler ve 6- Resmi yazışmalar yapar. Buradan da Cumhuriyet' in ilk yıllarında kütüphaneciliğin meslekî uzmanlık alanlarının henüz tam olarak belirlenmediği, netleşmediği anlaşılıyor. Lâyihada kütüphane memurunun eğitimi, uzmanlığı ya da sahip olması gereken özellikler hakkında bir bahis geçmemektedir. Ancak aynı görev sorumluluklara sahip memur muavinlerinin yüksekokul mezunu, bibliyografya bilgisine sahip ve Fransızcadan başka bir Avrupa dili bilen, ince ve okunaklı yazı yazabilen kimselerden atanacağı bilgisi bulunmaktadır. Bu özellikler de bir kütüphane memurunun en az hangi özellikleri haiz olması gerektiği açısından ipucu vermektedir (Candemir, 2004, s. 371).

Cumhuriyetin ilk yılarında kütüphanecilerin nitelikleri ile alakalı ilk bilgilerden birisi de bir gazete ilanında verilmektedir. Bu ilan, aynı zamanda İstanbul Arkeoloji Müzesinin personel kalitesini göstermesi bakımından önemlidir. Bu ilan İkdam gazetesine verilmiştir. İstanbul Arkeoloji Müzesi Kütüphanesi 1925 senesinde bir kişiyi kütüphanecilik alanında eğitim almak üzere Almanya'ya göndermek için gazetelere verilecek ilanda nasıl bir kütüphaneci profili arandığını bir nebze belirlemiş gibidir. İlanda Türk olmak, bir mahkûmiyeti olmamak, belli yaş aralığında olmak gibi genel şartların yanında aranan kişinin Almanca ve Fransızca bilmesi ve Üniversite (tercihen Edebiyat Fakültesi) mezunu olması istenmiştir (Koç, 2015, s. 157).

Görüldüğü üzere, klasik dönem hâfız-1 kütübleri ile Tanzimat’tan sonra karşımıza çıkan lâyiha ve nizamnâmelerle kurulan okul kütüphanelerinde istihdam edilen hâfız-1 kütübler arasında formasyon, yetki, görev ve sorumluluklar açısından büyük bir fark yoktur. Bu dönemde de hâfız-1 kütüb olarak tayin olunan kimseler, muhtelif başka görevlerinin yanı sıra kütüphanelerden de sorumlu tutulmuşlardır. Mesela Ayasofya Câmii Kütüphanesinin hâfız-1 
kütüblügüne aynı zamanda dersiâm olarak atanan Boyabatlı Osman Halis Efendi gibi, Konya İdâdî Mektebinde kütüphaneci olan Hasan Basri Efendi de, imamlık, hâfız-ı kütüblük ve ambar memurluğu görevlerini birlikte yürütmekteydi (Bilgili, 2016, s. 29). Tanzimat döneminde görev yapan Tıbhane-i Âmire kütüphanecisinin aynı zamanda okulun sekreter yardımcılığını, Tıbbiye-i Mülkiye hâfız-1 kütübü Hacı Arif Efendi'nin okulun matbaa müdürlüguünü yürüttüğü, Mühendishâne kütüphanesi hâfız-1 kütübünün aynı zamanda binbaşı rütbesinde görev yaptığı bilinmektedir (Bilgili, 2016, s. 31).

Klasik dönemde vakıflar bünyesinde istihdam edilen hâfız-1 kütüblerin Tanzimat'tan sonra resmi devlet memuru oldukları kabul edilebilir. Bu sürecin başlangıcı olarak II. Mahmud döneminde (sal. 1808-1839) Evkâf-1 Hümâyûn Nezâret'i kurularak vakıfların buraya bağlanması gösterilebilir (Candemir, 2004, s. 371). Tüzel kişilik bünyesinde bir nevi kamu hizmeti gören vakıflar bu şekilde merkezden yönetilir hale gelmiştir. Bu sebeple hâfız-1 kütüblerin de tayin, atama gibi resmi işleri bu şekilde devlet kontrolüne geçmiştir.

Türkiye'de modern anlamda kütüphanecilik Cumhuriyet dönemi ile birlikte başlamış, 1924 yılında Tevhid-i Tedrisat kanununun çıkarılması ile de kütüphaneler Maarif Vekâletine bağlanarak kurumsal bir kimlik kazandırılmıştır (Candemir, 2004, s. 367). Fakat bu süreçte Maarif Vekâletinin hâfız-1 kütüb adında resmî bir kadrosu mevcut olmamasına rağmen kütüphane görevlilerine yine hâfız-1 kütüb denmeye devam edilmiştir. ${ }^{5}$

\section{Türkiye Cumhuriyeti Döneminde Kütüphanecilik Eğitimi Faaliyetleri}

1924 yılında danışman olarak Amerika'dan davet edilen J. Dewey eğitim ile ilgili verdiği bir raporda, mevcut okul kütüphaneleri için kütüphanecilerin eğitilmesi gereğine değinmiş ve bu eğitimin Amerika' da yapılmasını, ayrıca öğretmen okullarında da kurslar verilmesini önermiştir (Dilek, 1991, s. 65). Dewey'in verdiği bu rapor doğrultusunda aynı yıl çalışmalar başlamış ve H. Fehmi Karatay “İstanbul Darülfünûnu Umûm Kütüphanesi” (İstanbul Üniversitesi Merkez Kütüphanesi)'ne yönetici olarak getirilmiştir. Maarif Vekâletince Fransa'ya 1 yıl yüksek lisans eğitimi almak üzere gönderilen Karatay, Türkiye'ye döndükten sonra Türkiye'de modern kütüphaneciliğin ilk temsilcisi olmuş ve kütüphanecilere meslekî bilgiler kazandırmak amacı ile ilk kütüphanecilik kursunu açmıştır (Candemir, 2004, s. 367). Maarif Vekâleti Hars Dairesi tarafindan yayınlanan “Kütüphaneler Kursu Talimatnâmesi”ne göre de İstanbul kütüphanelerinde çalışan bütün hâfız-1 kütüblerin açılan bu kursa katılmaları zorunlu tutulmuştur. Talimatnâmeye göre kütüphanecilik kurslarına en az ortaokul mezunu olanlardan isteyenlerin de katılabilecekleri ifade edilmiştir (Ötüken, 1979, s. 46).

5 Kütüphaneci yerine hâfız-1 kütüb ibaresinin kullanılmaya devam etmesinin sebebi o dönemde Osmanlı bakiyesi kütüphanelerde basma eserden çok yazma eserlerin bulunuyor olmasından olabilir (Dilek, 1991, s. 68). Diğer yandan ilim çevrelerinde işinin ehli eski kütüphanecilere saygı açısından ve bir bakıma da kullanım alışkanlığından dolayı bir süre daha hâfız-1 kütüb denilmeye devam etmiştir (Karataş, 2018, s. 79). 
Türkiye'de kütüphanecilik kurslarının başladığg yıl Hamit Zübeyir Koşay da Maarif Vekâletine "Kütüphanelere Dair I" adlı bir rapor vermiştir. Bu raporda ilk defa "Kütüphane bilimi” kavramı zikredilmiştir. Rapora göre kütüphanecilik mesleğinin bir bilim dalı olarak üniversitelerde yer alması gerektiği kaydedilmiştir (Candemir, 2004, s. 367). Aynı şekilde 1935 senesinde "Kütüphaneler Tasnif Komisyonu” başkanlığına getirilen Prof. Dr. Hellmut Ritter de "İstanbul Kütüphanelerinin Islâhı İçin Umûmî Plan" hazırlamıştır. Bu plana göre de kütüphanelerde eğitimli kütüphanecilerin çalıştırılması gerektiği vurgulanmıştır. Buna göre kütüphane memurları 3 seviyede değerlendirilmelidir. Birinci seviyedeki kütüphaneciler üniversite ve yazma eser kütüphanelerinde istihdam edilmelidir. Üniversite kütüphanesinde istihdam edilecek kütüphaneciler bir ilim dalında lisansını tamamladıktan sonra bir kütüphanede staj yapmış olmalıdır. Bunlar kendi ihtisas alanlarındaki kitapları takip ederek kütüphaneye kazandırılmasını teklif eder ve özel olarak o alandaki kitapları idare ederler (Ötüken, 1957, s. 43).

Birinci seviyede kabul edilip yazma eser kütüphanesinde istihdam edilecek kütüphaneciler de aynı şekilde lisans mezunu olmalı ve bunun yanı sıra Arapça, Farsça ve Osmanlı Türkçesi ile birlikte birkaç Avrupa diline vâkıf olmalıdırlar. Ritter raporun hazırlandığg tarihte İstanbul' da hâlihazırda böyle bir kütüphanecinin mevcut olmadığını ifade ederek yetiştirilmesi için acele edilmesini tavsiye etmiştir.

İkinci seviyede değerlendirilen kütüphaneciler birinci seviyedeki kütüphaneciler gibi lisans mezunu olmalı ancak Arapça, Farsça, Osmanlı Türkçesi bilip Avrupa dili bilmeyen kimselerden oluşmaktadır. O tarihte bu seviyede az sayıda kütüphaneci olduğu ifade eden Ritter sadece bunlarla çağdaş kütüphanecilik mesleğinin icra edilemeyeceğini belirtir.

Üçüncü seviyede değerlendirilecek kütüphaneciler ise herhangi bir yüksek tahsil yapmamış ve kütüphanecilik konusunda herhangi bir tecrübeleri olmayan memurlardır. Bu türden kütüphaneci sayısı fazla olup bunlar da kütüphanelerde teknik işlerde istihdam edilmelidir.

1936 senesinde ikinci kütüphanecilik kursu açılmıştır. O zaman Ankara Yüksek Ziraat Enstitüsü müdürü olan Dr. Josef Stummvol tarafindan Enstitü kütüphanesinde açılan kursa çeşitli vekâletlerden (bakanlıklardan) 30-40 kadar kütüphaneci katılmış ve üç ay süren kurs sonunda yapılan sınavda başarılı olanlara sertifika verilmiştir. Ancak bu kursun da H. Fehmi Karatay’ın açtı̆̆ı ilk kurs gibi devamı getirilmemiştir (Yılmaz, 1988, s. 8).

1942 senesine gelindiğinde ise Ankara Dil ve Tarih-Coğrafya Fakültesi tarafindan kütüphane memuru yetiştirmek amacı ile yeni bir kütüphanecilik kursu açma çalışmaları başlamıştır. Kurs o dönem Dil ve Tarih-Coğrafya Fakültesi dekan vekili olan Mehmet Emin Erişirgil’in desteği ile Adnan Ötüken tarafından açılmıştır. 1925 senesinde açılan kurstan farklı olarak bu sefer kursa katılacakların lisans mezunu ya da öğrencisi veya en az lise mezunu olması şartı getirilmiştir. Ancak yeterli kursiyer sayısına ulaşılamadığı takdirde ortaokul mezunlarının 
kursa katılmasına izin verilecektir (Ötüken, 1979, s. 52). Bu durum kütüphane memurlarının mümkün olduğunca eğitimli insanlardan seçilme gayretini göstermektedir.

Türkiye'de üçüncü kez açılan bu kütüphanecilik kursu bir yıl sürmüş ve 1952 yılına kadar yenilenerek devam etmiştir. 1944 senesinde bu kurslar için bir talimatnâme de hazırlanmıştır. Dil ve Tarih-Coğrafya Fakültesi tarafından yayınlanan talimatnâmede kursun amacı, kursiyer alım şartları ve ders müfredatları belirtilmiştir. Bu talimatnâmede kütüphanecilik mesleğinin gelişmesinin önemsendiği açıkça görülmektedir. Zira talimatnâmenin 2. maddesinde kursun amacının tamamen bilgili kütüphaneciler yetiştirmek, kütüphanecilerin meslekî bilgilerini artırmak ve kütüphaneciliğin meslek haline gelmesinde etkili olmak olduğu açıkça yazılmıştır (Alp, 2003, s. 67).

Adnan Ötüken'in açtığı kütüphanecilik kursu, idari bazı sorunlar yaşadığı için 1952 yılında kapatılmış, ancak 1953 senesinde Türk Dili ve Edebiyatı bölümünde zorunlu bir ders haline getirilerek kütüphanecilik eğitimlerinin devamı sağlanmıştır. 1954 senesinde ise aynı Dekanlığın girişimi ve Ankara Üniversite senatosunun da tasdiki ile kütüphanecilik eğitimi için ayrı bir bölüm açılmasına karar verilmiştir (Biçer, 2013, s. 130). 1954-1955 Eğitim-Öğretim yılında ise, ilk Kütüphanecilik Bölümü öğretim faaliyetine başlamıştır. Böylelikle bir zamanlar icra etmek için okuma yazma bilmenin yeterli görüldüğü kütüphanecilik mesleği, bundan sonra lisans seviyesinde eğitim almanın zorunlu olduğu bir meslek haline gelmiştir.

Ankara Dil ve Tarih-Coğrafya Fakültesi’nde açılan Kütüphanecilik bölümünden sonra 1972 yılında Hacettepe üniversitesinde lisansüstü düzeyinde kütüphaneci yetiştirmek amacı ile çalışmalar başlatılmış, ancak yeterli ilgiyi göremeyince 1974 senesinde lisans eğitimlerine başlamıştır. Daha sonraki yıllarda İstanbul Üniversitesi Edebiyat Fakültesi Kütüphanecilik Bölümü kütüphanecilik lisans eğitiminin yansıra yüksek lisans ve doktora eğitimleri vermeye başlamıştır. 2002 yılında ise Kütüphanecilik ve Arşivcilik bölümleri birleştirilerek Bilgi ve Belge Yönetimi Bölümü adını almıştır.

İlk ortaya çıktığı zamanlarda hâfız-1 kütüb olarak isimlendirilen ve temel yetkinlikleri okuma-yazma bilmek, güvenilir olmak ve kitapları korumak olan kütüphanecilik mesleği günümüzde sadece kütüphaneci olarak değil, kendi içinde üniversite kütüphanecisi, yazma eser kütüphanecisi, halk kütüphanecisi, danışma kütüphanecisi, dokümantasyon uzmanı, vs. gibi uzmanlık alanlarına ayrılmış ve artık gittikçe yaygınlaşan kullanımıyla, bilgi hizmetleri yöneticisi olarak da anılmaya başlamıştır. Bu adlandırmalar, bilgi üretim biçimlerine, kullanıcı taleplerine ve bilgi erişim yöntemlerine bağlı olarak gelişmeye ve değişmeye devam edecektir.

\section{SONUÇ}

Osmanlılarda hâfız-1 kütüblük bir meslek olarak 15. yüzyılda gelişmeye başlamış ve hâfız-1 kütüblerin görev tanımları ilk olarak Fatih döneminde vakfiyelerle tespit edilmiştir. Fakat bu 
vakfiyelerde görevin gerektirdiği niteliklerden daha çok meslekî olarak hâfız-1 kütüblerin yapması gereken işler üzerinde durulmuştur. Tanzimat'a kadar geçen sürede hâfız-1 kütüblerin formasyonu için herhangi bir yeterlilik kaydına rastlanmamıştır. Bu dönemde onların sadece güvenilir, ilim sahibi ve dindar kişiler olması üzerinde durulmuştur.

Tanzimat'tan sonra kurulan kütüphanelerde ise kütüphanecilerin sahip olması gereken şartlar farklılaşmış olmasına rağmen henüz meslekî bir formasyon için gerekli nitelikte alan tanımlamaları yapılmamış, bununla ilgili herhangi bir eğitim ve meslekî hususiyetler aranmamıştır. Bu durumun ise yüzyılın sonlarına doğru değişmeye başladığı görülmektedir. Tanzimat döneminde çeşitli okul kütüphanelerinin açılması ile hâfız-1 kütübler hem görevleri bakımından farklılaşmış hem de onlarda aranan nitelik ve şartlar kısmen de olsa belirlenmeye başlamıştır.

Cumhuriyet dönemine gelindiğinde ise kütüphanecilerde yeni meslekî nitelikler aranmış ve kütüphanecilik formasyonu tanımlanabilir hale gelmiştir. Bunun ilk adımı kütüphanecilik kurslarının açılması olmuştur. Bu kursların açılması ile mevcut kütüphanecilerin kurslara katılmaları zorunlu tutulmuş, daha sonra kütüphaneci olmak isteyenlerin bu kurslardan sertifika almış olmaları istenmiştir. 1954 yılından itibaren ise Ankara Üniversite Kütüphanecilik Bölümü’nün açılması ile bundan sonra kütüphaneci olmak isteyenlerin üniversite düzeyinde bir akademik eğitim alma zorunluluğu getirilmiştir.

Hakem Değerlendirmesi: Dış bağımsız.

Çıkar Çatışması: Yazar çıkar çatışması bildirmemiştir.

Finansal Destek: Yazar bu çalışma için finansal destek almadığını beyan etmiştir.

Peer-review: Externally peer-reviewed.

Conflict of Interest: The author has no conflict of interest to declare.

Grant Support: The author declared that this study has received no financial support.

\section{Kaynakça/References}

A. Fuad (1340). Kütüphanelerde sslahat münasebetiyle. Mihrab, 13-14, 449-452.

Alp, H. (2003). Cumhuriyet dönemi Türk kütüphaneleri ve kütüphaneciliği (1923-1950) (Yayımlanmamış yüksek lisans tezi). Marmara Üniversitesi, İstanbul.

Beydilli, K. (1997). Türk bilim ve matbaacılık tarihinde Mühendishâne ve Mühendishâne Matbaası ve Kütüphanesi (1776-1826). İstanbul: Eren.

Biçer, H. (2013). Osmanlı'dan cumhuriyete devralınan kütüphanecilik mirası: Cumhuriyet döneminde kütüphaneciliğin kurumsallaşması (Yayımlanmamış yüksek lisans tezi). İstanbul Üniversitesi, İstanbul.

Bilgili M. (2016). Osmanlı hafiz-ı kütübleri (Yayımlanmamış yüksek lisans tezi). İstanbul Üniversitesi, İstanbul. 
Candemir, M. (2004). Cumhuriyetin başlangıcında kaleme alınan İstanbul Darülfünunu Kütüphanesine ait bir dahilî nizamnâme lâyihası. Türk Kütüphaneciliği, 18(4), 363-384.

Çavdar, T. (1995). Tanzimat tan cumhuriyete kadar Osmanlı kütüphanelerinin gelişimi (Yayımlanmamış doktora tezi). İstanbul Üniversitesi, İstanbul.

Cunbur, M. (1962). Vakfiyelere göre eski Türk kütüphanelerinin yönetimi. Türk Kütüphaneciler Derneği Bülteni, 11(1-2), 3-21.

Cunbur, M. (1964a). I. Abdülhamid vakfiyesi ve Hamidiye Kütüphanesi. Ankara Üniversitesi Dil ve Tarih Coğrafya Fakültesi Dergisi, 22(1-2), 17-68.

Cunbur, M. (1964b). Tanzimat'ın kütüphaneciliğimize etkileri. Belleten, 28(112), 691-700.

Cunbur, M. (1964c). Münif Paşa ve kütüphanelerin yönetimiyle ilgili ilk resmi talimatnâme. Türk Kütüphaneciler Derneği Bülteni, 13(1-2), 28-34.

Cunbur, M. (1967). İlk dernek kütüphanemiz. Türk Kütüphaneciler Derneği Bülteni, 16(1), 2-9.

Dilek, H. (1991). Kütüphanecilik biliminin kapsamı ve Türkiye'de durum (Yayımlanmamış yüksek lisans tezi). İstanbul Üniversitesi, İstanbul.

Erünsal, İ. E. (Yay. haz.). (1990a). Kütüphanecilikle Osmanlıca metinler ve belgeler-I. İstanbul: İstanbul Üniversitesi.

Erünsal, İ. E. (Yay. haz.). (1990b). Kütüphanecilikle ilgili Osmanlıca metinler ve belgeler-II. İstanbul: İstanbul Üniversitesi.

Erünsal, İ. E. (1997). Hâfiz-ı kütüb. Türkiye Diyanet Vakfı İslam Ansiklopedisi (Cilt. 15, s. 94-98) içinde. İstanbul: Türkiye Diyanet Vakfı İslam Araştırmaları Merkezi.

Erünsal, İ. E. (2010). Türk kütüphaneciliğinde atılım dönemi. C. Yılmaz (Ed.), II. Abdülhamid: modernleşme sürecinde İstanbul içinde (s. 361-377). İstanbul: İstanbul 2010 Avrupa Kültür Başkenti.

Erünsal, İ. E. (2012). Sultan II. Abdülhamid dönemi Türk kütüphaneciliği ve kütüphaneleri. C. Yılmaz (Ed.), Sultan II. Abdülhamid ve dönemi içinde (s. 153-175). İstanbul: Sultanbeyli Belediyesi.

Erünsal, İ. E. (2020). Osmanlılarda kütüphaneler ve kütüphanecilik (3. bs.). İstanbul: Timaş Yayınları.

Gök, H. (2005). Arşiv belgelerinin ışığında kara harp okulu tarihi (1834-1883) (Yayımlanmamış doktora tezi). Hacettepe Üniversitesi, Ankara.

Günergun F. ve Yıldırım N. (2001). Cemiyet-i Tıbbiye-i Şahane'nin Mekteb-i Tıbbiye-i Şahane’ye getirdiği eleştiriler (1857-1867). Osmanlı Bilimi Araştırmaları, 3(1), 19-62.

Karataş, A. (2018). Son hâfiz-ı kütüblerden şâir Bekir Sıdkı Gencer. İstanbul: Kitaparası.

Kılıç, Y. (2016). H. 1332 (M. 1913) Tarihli Cemiyet-i Tedrisiye-i İslamiye salnamesi transkripsiyonu ve değerlendirmesi (Yayımlanmamış yüksek lisans tezi). Kırklareli Üniversitesi, Kırklareli.

Koç, H. (2015). İstanbul Arkeoloji Müzeleri Kütüphanesi (kuruluşundan cumhuriyete kadar). İ. Dağdelen, H. Türkmen, N. Ulu (Yay. haz.) Türk kütüphaneciliğinden izdüşümler Nail Bayraktar'a armağan-I (Hatıra ve Bilimsel Makaleler) içinde (s. 149-161). İstanbul: İstanbul Büyükşehir Belediye Başkanlığı.

Mekteb-i Cedid-i Harbiye-yi Şahane'nin idare-yi dahiliyesine dair kanunnamedir. (1263 [1847]). İstanbul: Takvimhane-yi Amire.

Ötüken, A. (1957). Prof. Hellmutt Ritter'in İstanbul kütüphaneleri hakkında mühim bir raporu. Türk Kütüphaneciliği Dergisi, 6(1-2), 36-46.

Ötüken, A. (1979). Kütüphaneciliğimiz için: milli kütüphane nasıl kuruldu ve Türkiye'de kütüphanecilik eğitiminin tarihçesi. Ankara: Türk Kütüphaneciler Derneği. 
Soysal, Ö. (1976). XIX ve XX. yüzyıllar Osmanlı siyasal yaşamının kütüphane kurumunu etkileyen iki olgusu. VIII. Türk Tarih Kongresi: Kongreye Sunulan Bildiriler (11-15 Ekim 1976) içinde (s. 250-261). Ankara: Türk Tarih Kurumu.

Sübki, T. (2019). Mu'idü'n-Ni'am: Makam ve meslek ahlakı. H. Özkan (Ed.); H. Yılmaz ve M. E. Midilli (Yay. Haz.). İstanbul: Türkiye Yazma Eserler Kurumu Başkanlığı.

Türkmen, H. (2001). Maarif-i umumiye nizamnâmesinin Türk kütüphanecilik tarihindeki yeri ve önemi. H. Y. Nuhoğlu (Der.). Osmanlı Dünyasında Bilim ve Eğitim Milletlerarası Kongresi Tebliğleri içinde (s. 643652.). İstanbul: İslam Tarih, Sanat ve Kültür Araştırma Merkezi (IRCICA).

Yılmaz, T. (1988). Türkiye'de yükseköğretim kapsamında kütüphanecilik eğitim programlarının değerlendirilmesi (Yayımlanmamış yüksek lisans tezi). Çukurova Üniversitesi, Adana. 